\title{
ANALISIS PELATIHAN DAN PENDAMPINGAN POTENSI SOSEK MELALUI PENDEKATAN TRAINING NEED ASSESMENT DI KOBALIMA TIMUR, PROVINSI NTT
}

\author{
Oleh: \\ Wiriadi Sutrisno ${ }^{1}$ \\ Novita Delima Puteri ${ }^{2}$ \\ Olos Wasahua ${ }^{3}$ \\ Dosen Program Studi Pendidikan Ekonomi \\ Fakultas Ilmu Pendidikan dan Pengetahuan Sosial \\ Universitas Indraprasta PGRI \\ Email: \\ wiriadisutrisno@gmail.com ${ }^{1}$
}

\begin{abstract}
ABSTRAK
Penelitian ini bertujuan untuk mengetahui jenis pelatihan apa yang sesuai dan dibutuhkan kawasan perbatasan, Kecamatan Koba Limu Timur, Provinsi NTT. Pelatihan dan pendampingan ditujukan untuk meningkatkan keterampilan masyarakat, agar mampu meningkatkan kondisi sosial dan ekonomi, baik dibidang pertanian, pengolahan produk olahan, rencana usaha, pengenalan bank, pengembangan kelembagaan khususnya pengembangan koperasi.

Penelitian dilakukan secara kualitatif dengan melakukan wawancara mendalam (in depth interview) untuk mengkonfirmasi kebenaran data tersebut juga dilengkapi dengan pengamatan dan wawancara kepada tokoh masyarakat. Dalam pengumpulan data tentang profil digunakan teknik-teknik seperti Focus Group Discussion (FGD) dan Particaptory Rural Appraisal (PRA).

Dengan melakukan serangkaian analisis, termasuk analisis SWOT, dilanjutkan dengan penerapan strategi Training Need Assesment (TNA), diperoleh paket pelatihan yang sesuai dengan kebutuhan masyarakat. Hasil dari penerapan paket pelatihan dan pendampingan, masyarakat Kobalima Timur, mampu meningkatkan pengetahuan dan peraktik pengembangan kelembagaan, khususnya koperasi, pengelolaan administrasi keuangan (Finon) dan pemerosesan peroduk olahan, Ceguong.
\end{abstract}

Kata Kunci: Pelatihan, Pendampingan, Sosek, TNA, FGD, PRA. 


\section{A. PENDAHULUAN}

Indonesia sebagai Negara Kesatuan Republik Indonesia (NKRI) terletak antara beberapa negara dan samudera. NKRI secara faktual dimana sebagian wilayah daratan berbatasan langsung dengan 3 (tiga) negara tetangga, salah satunya adalah Republik Timor Leste. Secara umum kondisi perekonomian di kawasan perbatasan Timor Leste, hingga saat ini taraf hidup penduduk yang berdomisili disana masih sangat memprihatinkan, khususnya terkait dengan rendahya tingkat kesejahteraan masyarakat lokal. Dengan kata lain, mereka hidup berada dalam kondisi miskin, pendidikan minim dan terbelakang. Disisi lain, secara umum dapat dikatakan bahwa kawasan perbatasan memiliki sumberdaya alam dan jasa-jasa lingkungan (SDAL) yang banyak dan berlimpah, baik sumberdaya hayati berupa flora dan fauna dengan keanekaragaman hayati yang tinggi (mega biodiversity) maupun sumberdaya nonhayati berupa hasil-hasil tambang dan migas, serta pemandangan alam yang indah yang potensial untuk kegiatan pariwisata alam (ecotourisme).

Kecamatan Koba lima Timur adalah salah satu wilayah perbatasan darat yang berada dalam wilayah Kabupaten Malaka, Provinsi NTT (Kupang, sebagai ibu kota provinsi), berdampingan langsung dengan Timor Leste. Secara administratif, Kecamatan Kobalima Timur, didukung oleh 4 (empat) Desa, yakni Desa Alas, Desa ALas Utara, Desa Alas Selatan dan Desa Alas Kotabiru serta diwilayah Kobalima Timur terdapat wilayah eks pengungsi dari Timor Leste yang bernama transmetamauk.

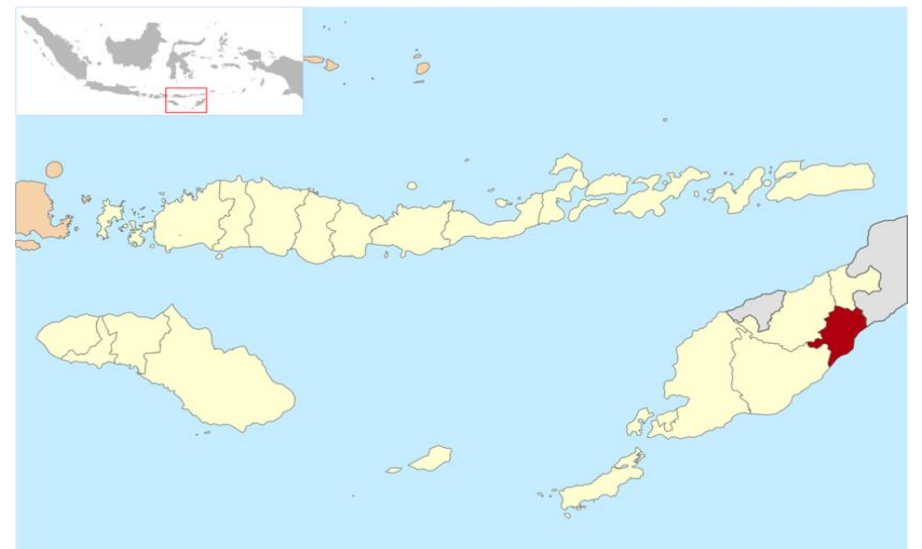

Gambar 1

Posisi Lokasi Kecamatan Kobaliima Timur

Kondisi masyarakat di sepanjang perbatasan umumnya miskin dengan tingkat kesejahteraan yang rendah dan tinggal di wilayah terisolir. Sumber mata pencaharian utama masyarakat di kawasan perbatasan adalah kegiatan pertanian lahan kering yang sangat tergantung pada cuaca dan iklim. Disamping itu, sarana dan prasanan transportasi masih berjarak jauh dengan lokasi pertanian yang dikelola petani. Kondisi ini juga menyebabkan tingkat kesejaahteraan masih pada level yang rendah. 


\section{B. KAJIAN PUSTAKA}

\section{Potensi Sosial dan Ekonomi}

\section{Pengertian Potensi}

Kartasapoetra (1987) dalam BNPP, 2015, mendefinisikan potensi adalah sesuatu hal yang dapat dijadikan sebagai bahan atau sumber yang akan dikelola baik melalui usaha yang dilakukan manusia maupun yang dilakukan melalui tenaga mesin dimana dalam pengerjaannya potensi dapat juga diartikan sebagai sumber daya yang ada di dasar kita.

Potensi yang dimaksudkan dalam program pendampingan ini adalah sumber daya alam (SDA) yang akan dikelola secara cermat oleh sumber daya manusia (SDM) dimana potensi tersebut menjadi suatu keterkaitan yang menyatu dalam pelaksanaan pelatihan pendampingan nantinya. Sehingga potensi yang ada disekitar lokpri dapat dijadikan modal dalam pembangunan

\section{Pengertian Potensi Sosial}

Pengertian Sosial disini yang dimaksudkan adalah segala sesuatu yang dipakai sebagai acuan dalam berinteraksi antar manusia dalam konteks masyarakat atau komunitas, sebagai acuan berarti sosial bersifat abstrak yang berisi simbol-simbol berkaitan dengan pemahaman terhadap lingkungan, dan berfungsi untuk mengatur tindakan-tindakan yang dimunculkan oleh individuindividu sebagai anggota suatu masyarakat. Sehingga dengan demikian, sosial haruslah mencakup lebih dari seorang individu yang terikat pada satu kesatuan interaksi, karena lebih dari seorang individu berarti terdapat hak dan kewajiban dari masing-masing individu yang saling berfungsi satu dengan lainnya. Dalam konteks ini, manusia diatur hak dan kewajibannya yang menunjukkan identitasnya dalam sebuah arena, dan sering disebut sebagai status, bagaimana individu melaksanakan hak dan kewajibannya sesuai dengan apa yang telah ada dalam perangkat pedoman yang ada yang dipakai sebagai acuan.

Dengan demikian potensi sosial adalah kemampuan individu dan kelmpok masyarakat dalam memenuhi hak dan kewajibannya dengan mengacu pada kearifan lokal dan ketentuan nsosial lainnya yaang sangat mempengaruhi pengembangan potensi individu dan masyarakat sebagai mahluk sosial (zoon politicoon)

\section{Pengertian Potensi Ekonomi}

Potensi Ekonomi adalah kemampuan suatu wilayah untuk menyediakan sumber peghidupan bagi penduduk dan tersedianya sumber daya di daerah tersebut. Potensi ekonomi daerah pada dasarnya dapat diartikan sebagai sesuatu atau segala sesuatu sumberdaya yang dimiliki oleh daerah baik yang tergolong pada sumberdaya alam (natural resources/endowment factors) maupun potensi sumberdaya manusia yang dapat memberikan manfaat (benefit) serta dapat digunakan sebagai modal dasar pembangunan (ekonomi) wilayah.

Blakely, Edward.J (1994) dalam BNPP (2015), mengatakan bahwa potensi sumberdaya ekonomi khususnya sumberdaya alam (natural resources/endowment factors) pada prinsipnya dapat dikategorikan menjadi 3 bagian, meliputi : a) 
sumberdaya alam yang tidak pernah habis (renewable-perpetual resources), b) sumberdaya alam yang tidak dapat diperbarui (non-renewable or exhaustible resources), c) sumberdaya alam yang potensial untuk diperbarui (potentially renewable resources).

Disamping komponen sumberdaya alam, pada saat ini peranan sumberdaya manusia (human resources) dalam konteks kegiatan pembangunan ekonomi termasuk pembangunan ekonomi daerah (wilayah) semakin signifikan. Faktor sumberdaya manusia ini telah menghadirkan suatu proses pemikiran baru dalam telaah teori-teori pembangunan ekonomi, yang menempatkan sumberdaya manusia sebagai poros utama pembangunan ekonomi baik dalam skala global, nasional maupun daerah. Strategi pembangunan ekonomi yang berbasis pada pengembangan sumberdaya manusia (human resources development) dianggap sangat relevan dan cocok dengan kondisi dan karakter pembangunan ekonomi.

\section{Konsep Pelatihan dan Pendampingan Masyarakat}

\section{Pelatihan}

Dalam BNPP (2015) mengemukakan pendapat para ahli antara lain Sikula dalam Sumantri (2000:2), mengartikan bahwa pelatihan sebagai: "proses pendidikan jangka pendek yang menggunakan cara dan prosedur yang sistematis dan terorganisir. Para peserta pelatihan akan mempelajari pengetahuan dan keterampilan yang sifatnya praktis untuk tujuan tertentu". Diungkapkan juga pandangan Good (1973) dalam Marzuki (1992) bahwa pelatihan adalah suatu proses membantu orang lain dalam memperoleh skill dan pengetahuan. Sedangkan Michael J. Jucius dalam Moekijat (1991 dalam BNPP (2015) menjelaskan istilah latihan untuk menunjukkan setiap proses untuk mengembangkan bakat, keterampilan dan kemampuan pegawai guna menyelesaikan pekerjaan-pekerjaan tertentu.

\section{Pengembangan Program Pelatihan}

Secara umum ada tiga tahap pada pelatihan yaitu tahap penilaian kebutuhan, tahap pelaksanaan pelatihan dan tahap evaluasi. Langkah-langkah yang umum digunakan dalam pengembangan program pelatihan, seperti dikemukakan oleh William B. Werther (1989:287) dalam BNPP (2015), pada prinsipnya pengembangan program pelatihan, meliputi (1) need assessment; (2) training and development objective; (3) program content; (4) learning principles; (5) actual program, (b) skill knowledge ability of works; dan (7) evaluation. Pendapat ini sesuai dengan yang dikemukakan Simamora (1997:3b) dalam BNPP (2015) yang menyebutkan delapan langkah pelatihan yaitu: (1). tahap penilaian kebutuhan dan sumber daya untuk pelatihan; (2) mengidentifikasi sasaran-sasaran pelatihan; (3) menyusun kriteria; (4) pre tes terhadap pemagang (5) memilih teknik pelatihan dan prinsip-prinsip proses belajar; (6) melaksanakan pelatihan; (7) memantau pelatihan; dan (8) membandingkan hasil-hasil pelatihan terhadap kriteria-kriteria yang digunakan. 


\section{Manajemen Pelatihan}

Manajemen pelatihan, dalam konteks yang lebih luas manajemen pelatihan memiliki dimensi tentang bagaimana pengelolaan pelatihan, supaya pelatihan bisa berjalan dengan baik dan berhasil secara efektif dan efisien. Menurut Irianto (2001), manajemen pelatihan secara konsep bisa diartikan "Proses perencanaan, pengorganisasian, penggerakkan dan Pengevaluasian terhadap kegiatan pelatihan dengan memanfaatkan aspek-aspek pelatihan untuk mencapai tujuan pelatihan secara efektif dan efisien". Dalam konteks yang lain manajemen pelatihan atau pengelolaan pelatihan identik dengan manajemen proyek atau pada istilah lain sama dengan mengelola proyek. Oleh karena itu daur Managing training dapat digambarkan sebagai berikut:

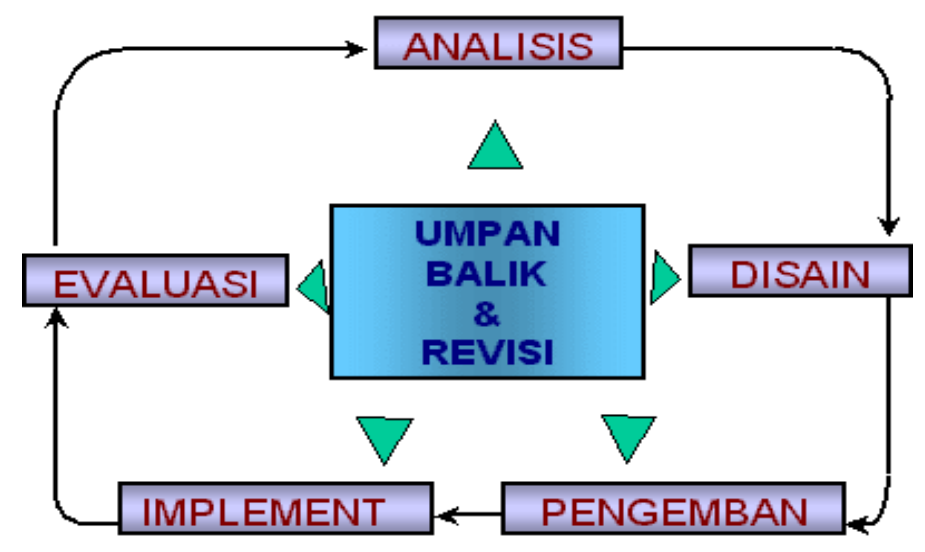

Sumber : Irianto Jusuf (2001)

Gambar 2

Skema Manajemen Pelatihan

\section{Konsep Training Need Assessment (TNA)}

\section{Pentingnya Training Needs Assessment}

LAN (1999) dalam [BNPP,2015], menjelaskan bahwa kebutuhan pelatihan dapat diketahui sekiranya terjadi ketimpangan antara kondisi (pengetahuan, keahlian dan perilaku) yang senyatanya ada dengan tujuan yang diharapkan tercipta pada suatu organisasi. Kebutuhan pendidikan (education needs) atau kebutuhan pelatihan (training needs) adalah kesenjangan yang dapat diukur antara hasil yang ada sekarang dan hasil yang diinginkan atau dipersyaratkan. Tidak semua kesenjangan atau kebutuhan mempunyai tingkat kepentingan yang sama untuk segera dipenuhi. Maka antara kebutuhan yang dipilih dengan kepentingan untuk dipenuhi kadang terjadi masalah atau selected gap.

Analisis Kebutuhan Pelatihan menurut Rosset dan Arwady dalam BNPP (2015), menyebutkan bahwa TNA adalah suatu istilah yang dipergunakan dalam analisis untuk memahami permasalahan kinerja atau permasalahan yang berkaitan dengan penerapan teknologi baru. Analisis kebutuhan pelatihan memegang peran penting dalam setiap program pelatihan, sebab dari analisis ini akan diketahui pelatihan apa saja yang relevan bagi suatu organisasi pada saat ini dan juga 
dimasa yang akan datang, yang berarti dalam tahap analisis kebutuhan pelatihan ini dapat diidentifikasi jenis pelatihan apa saja yang dibutuhkan oleh pegawai dalam pengemban kewajibannya.

\section{Pendekatan Training Need Assessment}

Menurut Marpaung (1999) dalam [BNPP, 2015], ada beberapa pendekatan dalam melakukan TNA, diantara yang paling populer adalah :

1) Makro, TNA yang didasarkan kepada kebutuhan organisasi / perusahaan secara umum, sehingga hasil TNA-nya berlaku untuk semua orang yang ada di dalamnya. Maka dari itu, seringkali disebut Organization-Based Analysis. TNA Makro dapat menggunakan sumber data diantaranya:
a. Visi, misi, strategic objective dan target lembaga
b. Keadaan ekonomi dan finansial kawasan.
c. Perubahan budaya.
d. Perubahan teknologi.
e. Strategi pengelolaan kawasan, seperti Pengurangan Biaya, Peningkatan Kualitas, dan hal-hal lain yang berkaitan engan dengan aspek makro

2) Mikro, TNA yang didasarkan kepada kebutuhan kelompok tertentu. Terdiri dari:

a. Task-Based Analysis, Fokus utamanya adalah apakah standar keterampilan yang dibutuhkan pada sebuah pekerjaan sudah dimiliki oleh si pemegang jabatan atau belum.

b. Person-Based Analysis, Fokus utamanya adalah apakah karyawan sudah dapat melakukan pekerjaan sesuai tuntutan atau belum. TNA Mikro dapat menggunakan sumber data diantaranya:
a) Job Description,
b) Performance Standar,
c) Performance evaluation,
d) Observasi kerja
e) Interview
f) Kuesioner
g) Checklist

\section{METODE PENELITIAN}

Penelitian yang dilakukan secara kualitatif dengan melakukan wawancara mendalam (in depth interview) untuk mengkonfirmasi kebenaran data tersebut juga dilengkapi dengan pengamatan dan wawancara kepada tokoh masyarakat. Dalam pengumpulan data tentang profil digunakan teknik-teknik seperti Focus Group Discussion (FGD) dan Particaptory Rural Appraisal (PRA), Chambers R. (2001) dalam [BNPP, 2015] 
Teknik PRA dilakukan sesuai panduan Chamber (1996) dan Towsley (1993) dalam BNPP (2015), Penerapan PRA adalah salah satu metode yang dipakai untuk menggali berbagai informasi dan kebutuhan nelayan dengan pendekatan yang praktis dan operasional .PRA adalah salah satu metode yang tekanananya bukan saja pada validitas ilmiah dari data yang diperoleh, namun lebih pada keterlibatan masyarakat dan tokoh masyarakat dalam menyampaikan berbagai informasi secara pasti, aspiratif dan mendalam. Berikut adalah fase penelitian yang dilakukan:

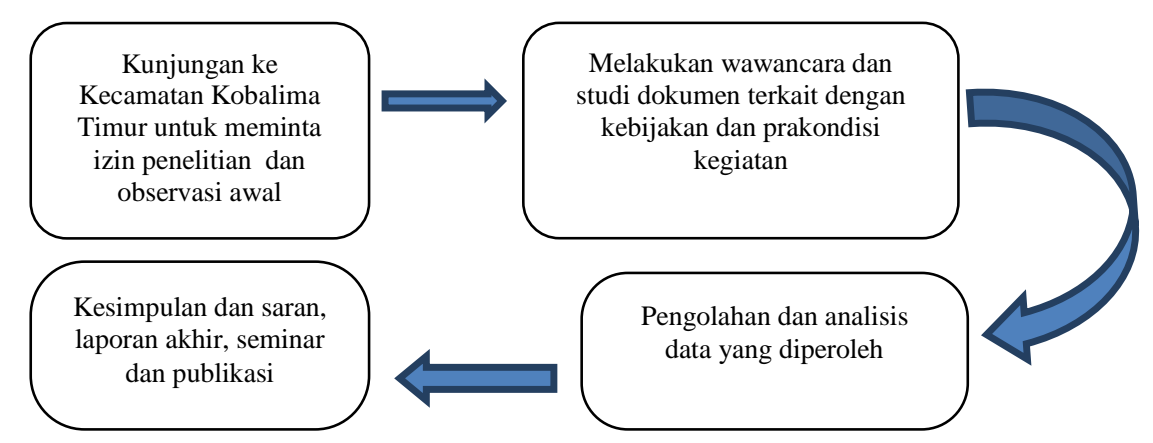

$$
\begin{aligned}
& \text { Sumber: Diolah oleh Tim Peneliti } \\
& \text { Gambar } 3 \\
& \text { Alur Tahapan Penelitian }
\end{aligned}
$$

Analisis data yang dilakukan pada penelitian ini adalah a) analisiss diskriptif, b) Analisis Pemangku Kepentingan (Stakeholders). c) Analisis Kelembagaan, dan d) Analisis SWOT, untuk mengidentifikasi berbagai faktor secara sistematis dalam rangka merumuskan strategi pengelolaan kawasan.

\section{HASIL DAN PEMBAHASAN}

Dari hasil olah data dan serangkaian analisis yang telah dilakukan di Kecamatan Kobalima Timur, Kecamatan Malaka, Provinsi NTT, diperoleh masukan yang pembahasannya dapat dicermati sebagai berikut:

\section{Analisis SWOT}

\section{Kekuatan (Strength)/S}

Dari hasil survey, diperoleh fakta bahwa kekuatan yang ada pada masyarakat/petani di Kecamatan Kobalima adalah: S01, Kondisi lahan, secara alami masih memiliki tingkat kesuburan yang baik. S02, Kesuburan tanaman dapat dilihat usaha pertanian dilakukan tanpa diberi pupuk (organic atau unorganic) tambahaan. S03, Secara budaya, masyarakat Kobalima memenuhi kebutuhan hidup dari bercocok tanam (bertani). S04, Wilayah Kobalima Timur, sudah tersentuh program pembangunan, berupa sarana dan prasarana, baik berupa jalan, baik tipe jalan propinsi, kabupaten maun tipe jalan daerah, listrik masuk desa dan pembangunan desa lainnya. S05, Posisi yang strategis, dekat potensi 
pasar, baik berdagang eceran (retail) maupun seacara bersama (karena diwilayah Kobalima Timur sudah ternentuk Koperasi) S06, Posisi supply yang kuat bagi penyediaan semua kebutuhan masyarakat Timor Leste, yang bersebelahan dengan perbatasan, karenan secara budaya, memiliki kesamaan pola dan cara hidup, jenis pakan yang dikonsumsi.

\section{Kelemahan (Weakness)/W}

Dari hasil temuan dilapangan, diperoleh unsur kelemahan pada masyarakat Kobalima Timur, sebagai berikut. W01, Pola pikir yang masih sederhana dan belum termotivasi untuk berbuat lebih baik sacara mandiri. W02, Kondisi SDM yang masih terbatas, baik secara teknis, administratif maupun manajemen, hususnya dalam meningkatkan hasil pertanian yang mereka peroleh W03, Kurangnya pelatihan yang intensif dan berkelanjutan dalam pengelolaan hasil pertanian, cara berdagang, usaha mandiri maupun pengetahuan tentang hubungan dengan pihak perbankan. W04, Kurangnya SDM penyuluh mandiri, yang dekat dengan masyarakat, sehingga dapat memberikan bimbingan teknis dan administrative pada saat diperlukan dengan segera. W05, Kurangnya pemahaman atas pemberian bantuan Pemerintah. Masih beranggapan bahwa bantuan yang bermanfaat adalah bantuan bersifat tunai, tanpa memahami bahwa bantuan bersifat pelatihan sangat dan lebih besar manfaatnya.

\section{Kesempatan (Oppurtunities)/ O}

Kesempatan yang bisa diperoleh oleh masyarakat Kobalima Timur adalah: O01, Melakukan kegiatan bisnis, dan usaha disektor sosiaal ekonomi lainnya, karena Pemerintah sudah membangun sarana dan prasarana, baik berupa jalan ber hot mix, peneraangan dan bantuan pembangunan sumur dan bak air, sebagai sumber ar minum. O02, Masyarakat memiliki pengetahuan dalam meningkatkan keterampilan dan mengolah produk olahan hasil tani, karena Pemerintah sudah sangat aktif melakukan kegiatan pendampingan dan pelatihan, guna meningkatkan keterampilan masyarakat, baik di bidang pertanian, peternakan dan kegiatan sosial ekonomi lainnya. O03, Masyarakat akan mampu memperoleh kehidupan yang lebih layak dengan fasilitas yang telah diberikan Pemerinah, baik berupa pembngunan sarana dan prasarana maupun bantun berupa pendidikan. O04, Masyarakat akan memiliki pemikiran yang terbuka (open mind), dan menerima perubaha4, yang tidak bertentangan dengan kearifan dan budaya lokal.

\section{Ancaman (Threats)/T}

Ancaman yang sangat dekat jika Pemerintah tidak melakukan pendampingan secara aktif adalah: T01, Tingkat kemiskinan, penggangguran akan terus meningkat. T02, Kondisi kesehatan masyarakat akan terus menurun T03, Kegiatan illegal semangkin meningkat, seperti melakukan transaksi bisnis tanpa dilindungi dokumen yang syah. T04, Terjadi exodus, besar besaran ke negara tetangga, karena mereka be asumsi, bahwa kehidupan dinegara tetangga lebih baik. 
Uraian analisis SWOT dapat difahami dengan jelas dengan mengamati matrix sebagai berikut:

\begin{tabular}{|l|c|c|}
\hline & $\begin{array}{c}\text { Strength/S } \\
\text { Eksternal }\end{array}$ & $\begin{array}{c}\text { Weakness/W } \\
\text { Internal }\end{array}$ \\
\hline $\begin{array}{l}\text { Oportunities/O S02, S03, S04, S05, S06 }) \\
(\mathbf{O 1}, \mathbf{O 0 2}, \mathbf{O 0 3}, \mathbf{O 0 4})\end{array}$ & SO W02, W03, W04, W05) \\
\hline $\begin{array}{l}\text { Threat/T } \\
(\mathbf{T 0 1}, \mathbf{T 0 2}, \mathbf{T 0 3}, \mathbf{T 0 4})\end{array}$ & ST & WO \\
\hline
\end{tabular}

\section{Matrix Analisis SWOT}

Dari analisis SWOT, WT adalah simbol yang sangat kritis terjadi pada Masyarakat Kecamatan Kobalima Timur. Karena keterbatasan kemampuan, hasil tani hanya digunakan sebagai konsumsi untuk memenuhi kebutuhan pangan sehari hari. Sehingga petani tidak memperoleh nilai tambah dari hasil panen yang diperoleh dan hal ini menyebabkan kesejahteraan masyarakat tidak mengalami kemajuan hari demi hari. Banyak permasalahan sosial ekonomi yang dialami masyarakat Koba Lima Timur, yang perlu segera dicarikan solusinya terutama mengenai pengembangan produk turunan hasil utama ketela, jagung dan pisang.

Permasalahan yang dihadapi masyarakat Kobalima Timur, antara lain adalah: a)Tidak dimilikinya pengetahuan tentang pengembangan hasil pertanian seperti ketela, jagung dan pisang menjadi produk turunan yan memiliki nilai tambah yang tinggi. b) Tidak dimilikinya sarana dan prasarana untuk mengolah hasil pertanian menjadi produk turunan. c) Tidak mengetahui bagaimana caranya mengolah hasil pertaniaan, menjadi suatu usaha tani terpadu. d) Tidak mengetahui baagaimana cara memasarkan hasil tani dan produk turunan dan dimana pasar (calon pembeli) yang minat akaan produk tani yang dihasilkan. e) Tidak mengetahui bagaimana caranya membuat perencanaan usaha dan memohon bantuan dana kepada Bank

\section{Strategi TNA}

Dengan mengacu pada kondisi yang ada pada masyarakat Kobalima Timur serta analisis SWOT (KEKEPAN) yang sudah dilakukan, maka disimpulkan strategi yang tepat dan sesuai untuk memenuhi kebutuhan pelatihan/pendampingan bagi masyarakat Kobalima Timur adalah sebagai berikut:

a. Pendampingan/pelatihan pengelolaan hasil panen ketela, jagung dan pisang menjadi produk turunan yang memiliki nilai tambah tinggi, dan memiliki pangsar pasar yang luas. Produk turunan yang ada pada perioritas utama adalah: 
i. Pelatihan pengelohan Ketela, menjadi produk turunan Sagu dari ampas ketela (sari patinya, bisa dijadikan tepung kanji /cassava)

ii. Pelatihan membuat susu jagung

iii. Pelatihan membuat keripik pisang

b. Pendampingan Kewirausahaan (Usaha Mandiri)

i. Pelatihan bagaimana memulai usaha mandiri dikaitkan dengan apa yang dimiliki

ii. Pelatihan bagaimana melakukan pencatatan tentang penggunaan bahan

iii. Pelatihan bagaimanan melakukan pencataatan keuangan (finon)

iv. Pelatihan bagaimana membuat rencana usaha

c. Pendampingan tentang pembentukan kelembagaan (KUT, GAPOKTAN dan KOPERASI)

d. Pendampinan Membuat Proposan Bantuan Dana Ke Bank

\section{Hasil Pendampingan Dari Penerapan TNA}

Hasil Pendampingan Sosial Ekonomi, khususnya mengenai Kelembagaan Dan Koperasi dan Penguasaan pengelolaan Finon (Pengelolaan keuangan bagi orang yang bukan mempunyai profesi bukan dibidang keuangan)

\section{Hasil Pendampingan Kelembagaan Dan Koperasi}

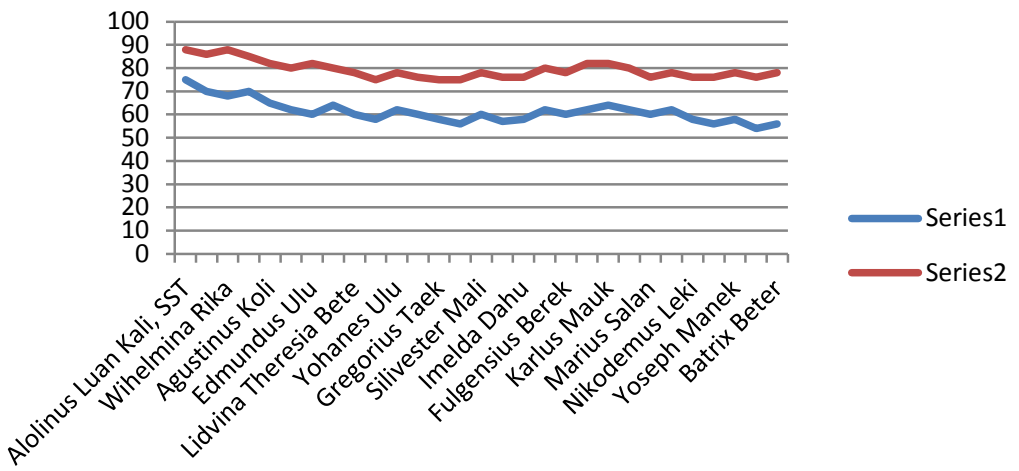

Sumber: Diolah oleh Tim Peneliti

Grafik 1

Perkembangan Pre test dan Post Test Pendampingan Kelembagaan Dan Koperasi Di Kecamatan Kobalima Timur, Kab. Malaka Prov. NTT

Hasil pre test rata rata para peserta menunjukan hasil rata-rata yakni 61,73. Artinya, pengertian peserta tentang keberadaan dan fungsi kelembagaan dan koperasi sudah cukup baik. Karena pengembangan kelembagaan dan Koperasi di Kobali Timur memang pernah diterapkan. Dengan adanya pendampingan, pemahaman tentang fungsi dan manfaat kelembagaan dan koperasi secara signifikan terlihat semangkin mapan. Hasil post test yang dicapai rata-rata 79,6. Terjadi peningkatan yang signifikan yakni 29,3\%. Dengan demikian dapat 
disimpulkan bahwa pendampingan pengenalan kelembagaan dan koperasi yang dilakukan, dapat meningkatkan pemahaman para peserta tentang kelembagaan dan koperasi dan manfaat apa saja yang akan diperoleh. Ukuran ini dapat dilihat dengan adanya respons positif pada saat dilakukan simulasi pembentukan koperasi dan mewacanakan nama koperasi kelak akaan berupa Koperasi Serba Usaha HADOMI (yang berarti cinta/kasih/sayang), BNPP (2015)

\section{Hasil Pendampingan Pengelolaan Finon}

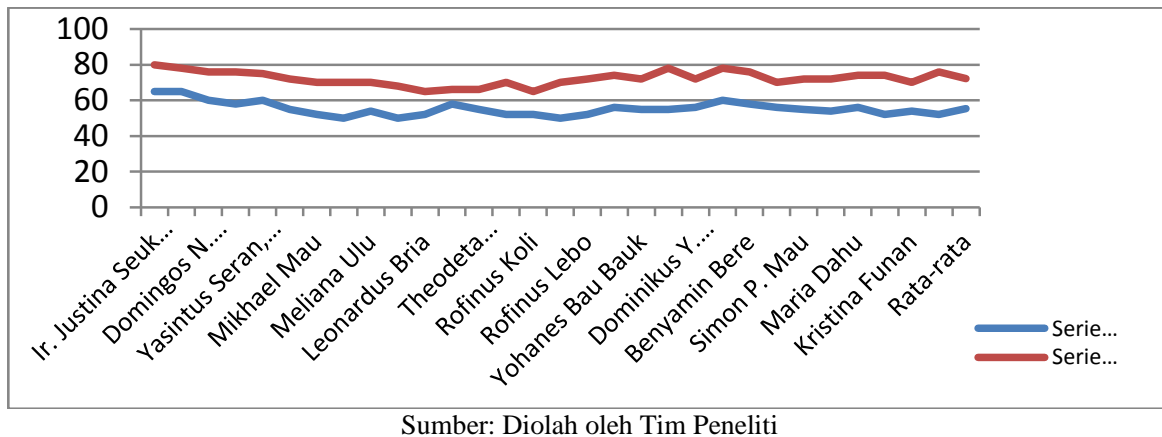

Grafik 2

Perkembangan Pre test dan Post Test Pendampingan Finon Kobalima Timur, Kabupaten Malaka.

Peraktek FINON dilakukan dengan membuat simulasi pencatatan setiap transaksi, memilah milah jenis pengeluaran, membedakan antara pengeluaran usaha dan pengeluaran non usaha, membukukan kegiatan pengeluaaran dan penerimaan kebuku khusus dan cara menghitung laba dan rugi. Selanjutnya dilakukan pendampingan bagaimana membuat proposal usaha untuk memperoleh bantuan dana dari Bank. Untuk mengukur tingkat penyerapan dan pemahaman materi administrasi kelompok, kepada peserta pada awal acara dilakukan pre test dan diakhir acara dilakukan post test.

Sebelum penyampaian materi Finon dilakukan, TA memberikan pre test kepada para peserta, dan hasilnya sangat mengejutkan bahwa pemahaman mereka tentang pencatatan keuangan secara sederhana ada dibawah rata-rata, yakni 55,6. Meskipun ada nilai yang diatas rata-rata, yakni para peserta yang memiliki latar belakang aktif ikut dalam kegiatan organisasi baik gereja, kelompok tani dan koperasi. Setelah materi pelatihan Finon hampir usai, TA memberikan post test tentang pemahaman Finon. Hasilnya cukup memuaskan yakni rata rata 75,7. Dengan demikian diperoleh peningkatan kemampuan secara relatif $36,1 \%$. 


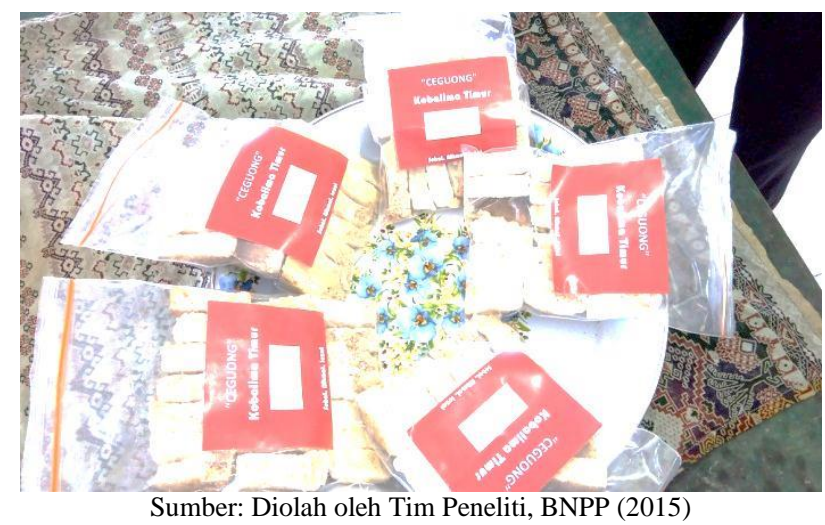

Gambar 1

Hasil Pendampingan Keterampihan Produk Olahan CEGUONG

Ceguong adalah bukti fisik dari hasil pendampingan yang dilakukan oleh Tim Peneliti, dengan memanfaatkan limbah singkong yang dikenal dengan Onggok (ampas singkong), dimana sari pati singkong sudah diolah menjadi tepung Kanji/Aci (Casava).

\section{E. SIMPULAN}

Dari rangkaian kegiatan yang sudah dilakukan diwilayah Kecamatan Kobalima Timur, baik dimulai dari survey awal (TNA) sampai dengan fase pendampingan pelatihan potensi sosial dan ekonomi lokal, dapat disimpulkan hal-hal sebagai berikut:

a. Mata pencaharian masyarakat Kobalima Timur dapat dipetakan dengan profesi sebagai pegawai negeri, pegawai swasta, berdagang, dan bertani. Mata pencarian sebagai petani adalah mata pencahari yang utama. Namun hasil tani dijual kepada pedagang yang langsung datang ke ladang/kebun. Hal ini adalah pilihan yang paling aman, mengingat lokasi pasar sangat jauh dari kediaman petani (Keva dan Belu). Disisi lain, pasar internasional (wilayah Timor Leste), sangat dekat dengan wilayah Kobalima Timur.

b. Dikaitkan dengan luas lahan pertanian, yang menjadi potensi sosial dan ekonomi lokal adalah sektor pertanian, baik tanaman padi, sayur, buah dan tanaman pangan lainnya

c. Pemerintah telah melakukan pelatihan pendampingan peningkatan potensi lokal, memberikan bantuan alat pertanian, sudah tepat. Namun diperlukan waktu pendampingan yang lebih intensif dan berkelanjutan.

d. Keterampilan masyarakat dalam mengolah hasil pasca panen, baik buah, jagung, pisang, ketela sangat diperlukan dalam rangka menunjang program pemerintah mengenai ketahanan pangan nasional. 
e. Cemilan atau snack yang berasal dari ampas singkong, merupakan alternatif panganan kecil, yang dapat menghasilkan nilai tambah masyarkat krayan. Perlu disosialisasikan secara inntensif dan integratif agar dapat membantu masyarakat mengolah bahan baku yang tadinya tidak memiliki nilai ekonomis menjadi memiliki nilai ekonomis yang tinggi. 


\section{DAFTAR PUSTAKA}

[BNPP], 2015 , Pendampingan Pengelolaan Potensi Sosial dan Ekonomi Lokal Kawasan Perbatasan, Laporan Akhir, Badan Nasional Pengelolaan Perbatasan, Jakarta

[LAN], 1999, Model-Model Diklat Analisis Kebutuhan Diklat. Pembinaan dan Pelatihan Teknik Menejemen, Lembaga Administrasi Negara, Jakarta.

Blakely, Edward.J., 1994, Planning Local Economic Development, Theory and Practice, 2nd edition, Sage Publication

Chamber (1996) dan Towsley (1993) dalam BNPP (2015) Pendampingan Pengelolaan Potensi Sosial dan Ekonomi Lokal Kawasan

Perbatasan, Laporan Akhir, Badan Nasional Pengelolaan Perbatasan, Jakarta

Chambers R. 2001. PRA, Participatory rural appraisal - memahami desa secara OXFAM partisipatif. Cetakan ke -8 Penerbit Kanisius dan Yogyakarta, $114 \mathrm{hlm}$

Irianto Jusuf , 2001, Prinsip-prinsip Dasar Manajemen Pelatihan Pelatihan), Insani Cendekia, Jakarta

(Dari Analisis Kebutuhan Sampai Evaluasi Program

Kartasapoetra (1987) dalam BNPP, 2015, Pendampingan Pengelolaan Potensi Sosial dan Ekonomi Lokal Kawasan Perbatasan, Laporan Akhir, Badan Nasional Pengelolaan Perbatasan, Jakarta

Marpaung, Dr, MSc., 1999. Training Need Assesment (TNA), LAN RI, Jakarta.

Marzuki, M.S, 1992, Strategi dan Model Pelatihan, Malang : IKIP Malang.

Moekijat, (1990), Pengembangan dan Motivasi, Bandung : Pionir Jaya.

Rossett,Allison,Traininingm 1987, Needs Assessment,Educational Technology Publicatin Englewood Cliffs,New

Sikula dalam Sumantri (2000:2), Pendampingan Pengelolaan Potensi Sosial dan Ekonomi Lokal Kawasan Perbatasan, Laporan Akhir, Badan Nasional Pengelolaan Perbatasan, Jakarta 
Simamora (\}997 : 3b) dalam BNPP (2015), Pendampingan Pengelolaan Potensi Sosial dan Ekonomi Lokal Kawasan Perbatasan, Laporan Akhir, Badan Nasional Pengelolaan Perbatasan, Jakarta

William B. Werther (1989 : 287) dalam BNPP (2015), Pendampingan Pengelolaan Potensi Sosial dan Ekonomi Lokal Kawasan Perbatasan, Laporan Akhir, Badan Nasional Pengelolaan Perbatasan, Jakarta 